\title{
A CONSTRUÇÃO DOS MÁRTIRES DA LIBERDADE NO DOCUMENTÁRIO JE SUIS CHARLIE
}

\author{
The building of the freedom martyrs in the documentary Je Suis Charlie \\ La construcción de los mártires de la libertad en el documental Je Suis Charlie \\ Helene Ayoub Franzon \\ Mestre em Comunicação pela Universidade Estadual de Londrina (UEL) \\ helenefranzon@gmail.com \\ André Azevedo da Fonseca \\ Professor Associado na Universidade Estadual de Londrina (UEL). \\ Doutor em História pela Universidade Estadual Paulista (Unesp) \\ andre.azevedo@uel.br
}

\section{Resumo}

Em 2015, um atentado terrorista à sede do semanário satírico francês Charlie Hebdo causou comoção mundial. As manifestações de repúdio à violência fizeram com que a frase "Je Suis Charlie" (Eu sou Charlie) viralizasse pelas redes sociais. Assim, o periódico e os cartunistas assassinados passaram a ser reverenciados como verdadeiros mártires da liberdade. O objetivo desta pesquisa é analisar as mitologias que o documentário Je Suis Charlie (2015) manipulou para reforçar uma conotação sagrada dessa história. Para isso, efetuamos uma análise fílmica a partir da perspectiva da mitocrítica. Concluímos que a narrativa documental foi estruturada de modo a mitificar o periódico a partir do contraste do heroísmo dos cartunistas com um aspecto sombrio do islamismo.

Palavras-chave: Charlie Hebdo. Jornada do herói. Mitocrítica.

\begin{abstract}
In 2015, a terrorist attack on the head office of the French magazine Charlie Hebdo caused a worldwide commotion, and the slogan "Je Suis Charlie" (I am Charlie) went viral on the internet. Amidst the tributes, the newspaper and the murdered cartoonists began to be revered as sacred symbols of freedom. The purpose of the present research is to analyze the mythologies that the documentary Je Suis Charlie (2015) manipulated in order to attribute a sacred meaning to this story. To this end, a film analysis was made based on the perspectives of mythcriticism. It was verified that the documentary narrative was structured in such a way as to mystify the journal from the contrast of cartoonists' heroism with a dark aspect of Islamism.
\end{abstract}

Key words: Charlie Hebdo. Hero's Journey. Mythcriticism. 


\section{Resumen}

En 2015, un ataque terrorista en la sede del semanario satírico francés Charlie Hebdo causó conmoción en todo el mundo. Las manifestaciones de repudio a la violencia hicieron que la frase "Je Suis Charlie" (Soy Charlie) se volviera viral en las redes sociales. Así, el periódico y los dibujantes asesinados llegaron a ser venerados como verdaderos mártires de la libertad. Esta investigación analiza las mitologías que el documental Je Suis Charlie (2015) manipuló para reforzar una connotación sagrada de esta historia. Para ello, se realizó un análisis fílmico desde la perspectiva del mitocrítico. Se concluyó que la narrativa documental estaba estructurada para crear una mística alrededor del periódico a partir del contraste del heroísmo de los dibujantes con un aspecto oscuro del islam.

Palabras clave: Charlie Hebdo. El viaje del héroe. Mitocrítica

\section{O ATENTADO TERRORISTA AO CHARLIE HEBDO}

No dia 7 de janeiro de 2015, um atentado à sede do semanário satírico Charlie Hebdo, em Paris, provocou 12 mortes e deixou 11 pessoas feridas. Os identificados como responsáveis pelo ataque foram os irmãos Saïd Kouachi e Chérif Kouachi, ambos nascidos na França, filhos de imigrantes argelinos (HIGGINS; BAUME, 2015). Entre as vítimas do ataque estavam renomados profissionais, como o editor e cartunista Stéphane Charbonnier, o Charb; além dos cartunistas Georges Wolinski; Jean Cabut, o Cabu; e Bernard Verlhac, o Tignous. Após o atentado, a frase "Je suis Charlie" (Eu sou Charlie) viralizou em todas as redes sociais. Jornalistas e ilustradores do mundo todo se manifestaram sobre a grande perda da imprensa livre, enquanto veículos de comunicação noticiavam o acontecimento com riqueza de detalhes.

O ataque não foi um fato isolado na história do semanário. Os conflitos com a comunidade islâmica, por conta de publicações consideradas ultrajantes por seguidores da religião, se arrastavam há vários anos (VEJA, 2015). Mas devido à dimensão da violência, o atentado causou impactos no imaginário do século 21 . Já na cobertura da tragédia, a imprensa mundial passou a apresentar o Charlie Hebdo como um ícone dos ideais mais caros da civilização ocidental: a liberdade de expressão.

Relativamente desconhecido fora da França até então, o jornal foi objeto de incontáveis reportagens, programas de televisão e documentários que narraram o atentado pelos mais variados vieses. E neste processo, os cartunistas passaram a ser idolatrados como heróis que haviam sido martirizados por defenderem esses valores sagrados. Em outras palavras, a imagem do Charlie Hebdo na mídia ocidental parecia se tornar aquilo que mais satirizava: um símbolo sagrado. 
O objetivo desta pesquisa é analisar as mitologias que um vídeo-documentário manipulou em sua narrativa para atribuir esse sentido sagrado à imagem do periódico francês. Por ser veiculado na Netflix, Je Suis Charlie (2015), dirigido por Daniel Leconte e Emmanuel Leconte, se tornou uma das produções jornalísticas mais populares sobre o tema. O próprio título, além de reverberar o slogan que viralizou pelo mundo todo, já indica o claro viés apologético ao Charlie Hebdo. "Um documentário que homenageia as vítimas e mostra as consequências do terrível atentado ao Charlie Hebdo, na França", registra a sinopse.

O filme nos mostra a história do jornal e de sua equipe por uma perspectiva menos propriamente biográfica do que, na prática, hagiográfica; pois o foco se concentra na homenagem ao trabalho criativo dos cartunistas, no impacto internacional do atentado e no choque para todos os funcionários do periódico - cujos depoimentos são explorados com sensibilidade ao longo da narrativa. Contudo, em que medida o documentário contribuiu para, em meio à comoção internacional, sacralizar as qualidades atribuídas ao jornal através da manipulação de uma mitologia heroica, em contradição ao próprio espírito iconoclasta do periódico? E em termos mais específicos: de que modo a estrutura da jornada do herói mitológico, tal como reproduzida à exaustão em manuais contemporâneos de roteiro, influenciou as representações que o documentário atribuiu aos cartunistas?

\title{
2 O MITO NA ANÁLISE FÍLMICA
}

Sabemos que um filme é o resultado de um processo complexo que inclui diversas etapas, que estão alinhadas, necessariamente, ao pensamento e ao ponto de vista da equipe de direção. Por isso, Vonoye e Goliot-Lété (1994) propõem que uma análise fílmica deve decodificar precisamente esses processos de concepção visual e sonora da obra.

\begin{abstract}
A escrita do roteiro, a decupagem técnica, a filmagem, a montagem e a mixagem constituem as etapas de um processo de criação de fabricação de um produto. A descrição e a análise procedem de um processo de compreensão, de (re)constituição de um outro objeto, o filme acabado, passado pelo crivo da análise, da interpretação. (VONOYE, GOLIOT-LÉTÉ, 1994, p.12)
\end{abstract}

Do mesmo modo, a linguagem empregada no filme também é resultado da visão de mundo do cineasta. Isso quer dizer que a sensação de "realidade" da obra depende da visão dos criadores que, conscientemente ou não, jamais deixam de expressar seus sonhos e ideologias. Ainda que muitos diretores tenham a objetividade como meta, contar uma história 
implica em escolher uma perspectiva. "Deveria ficar claro, neste ponto, que o cinema possui uma faculdade única e jamais reconhecida em qualquer outra arte: a de transformar o mundo em discurso e servindo-se do próprio mundo" (MOSCARIELLO, 1985, p. 10).

Portanto, a análise fílmica parte do princípio de que a obra cinematográfica não é apenas um produto artístico, mas um documento histórico e cultural. $\mathrm{O}$ trabalho do pesquisador, portanto, consiste em decodificar esse discurso. Para isso, em termos metodológicos, a análise de um filme implica em, primeiramente, dividi-lo em fragmentos através da seleção de "eixos temáticos", para, em seguida, reconstruir o filme através da junção dos elos isolados. "A desconstrução equivale à descrição. Já a reconstrução corresponde ao que se chama com frequência de "interpretação" (VONOYE, GOLIOT-LÉTÉ, 1994, p.15).

Tendo em vista que o interesse da pesquisa é identificar as mitologias presentes no discurso do documentário, a obra foi analisada através da perspectiva dos estudos de mitocrítica. Partimos do princípio de que, ao perceber que as narrativas mitológicas continuavam fascinando o público no contexto da sociedade de consumo, as indústrias culturais se interessaram pelas perspectivas psicanalíticas e antropológicas da mitologia e passaram a empregar arquétipos, símbolos naturais e narrativas míticas de forma deliberada nas produções.

Campbell (1997) publicou obras influentes no campo da Antropologia para demonstrar que as narrativas de incontáveis mitologias possuem muitos pontos convergentes porque se estruturam a partir do mesmo modelo, mesmo em culturas distintas. Ao criar histórias a partir de uma base arquetípica comum, as fábulas e os mitos se tornam universais, a despeito das particularidades dos contextos em que são forjados. Partido destas descobertas, Vogler (2006) se tornou célebre na indústria cinematográfica ao transformar as teorias de Campbell em uma espécie de manual de redação de roteiros. Ele observou que os estágios da Jornada do Herói são recorrentemente empregados para estruturar histórias de modo a provocar o fascínio nos consumidores. Assim, este roteirista e consultor parece ter criado uma espécie de "fórmula" para roteiros cinematográficos que, se observarmos o padrão atual do cinema de Hollywood, tem sido o modelo dominante.

Para analisarmos de que modo o documentário Je Suis Charlie utiliza-se de mitologias durante a narrativa, precisamos observar não apenas a definição junguiana de arquétipo, mas as formas adaptadas - e às vezes simplificadas - pela qual este conceito tem sido utilizado na produção cultural. Para Jung, arquétipos são conteúdos do inconsciente 
coletivo que, em última instância, se expressam individualmente nos sonhos e coletivamente nos mitos e nos contos de fada. Contudo, o conceito junguiano de arquétipo se aplica apenas indiretamente no campo das representações coletivas, pois o termo se refere mais especificamente aos conteúdos psíquicos que ainda não foram submetidos à elaboração consciente. "É inútil decorar uma lista de arquétipos. Estes são complexos de vivência que sobrevém aos indivíduos como destino e seus efeitos são sentidos em nossa vida mais pessoal" (JUNG, 2002, p. 39).

No entanto, através de uma perspectiva pragmática, este conceito complexo tem sido reinterpretado e reapropriado pela indústria cultural de forma a favorecer a sua instrumentalização. E foi assim que, no jargão de produtores de conteúdo nas mídias, o termo "arquétipo" passou a significar um conjunto mais ou menos coeso de características que definiriam a estrutura de personagens míticos em histórias sagradas, como o herói (o protagonistas das histórias), a sombra (o vilão que encarna todo o mal), o arauto (aquele que lança um desafio para o herói), o mentor (o velho sábio que treina o herói), o pícaro (os palhaços ou as manifestações cômicas) ou o camaleão (um personagem instável que se transforma durante a narrativa), entre outros.

Vogler (2006) admite que esses arquétipos não precisam necessariamente ser fixos, pois podem manifestar qualidades contraditórias e sofrer transformações substanciais durante a narrativa. "Pode-se pensar nos arquétipos como máscaras, usadas temporariamente pelos personagens à medida que são necessárias para o avanço da história” (VOGLER, 2006, p. 49). Em uma mesma narrativa, por exemplo, o mocinho pode exibir traços de malandragem, ou o vilão pode esboçar alguma moralidade. Essas calculadas oscilações aproximam o personagem fictício das contradições inerentes da natureza humana, que sempre foram expressos com ambiguidade nos mitos ancestrais.

Independentemente do gênero da narrativa - seja ela oral, literária ou fílmica - a figura do herói sempre causou impactos na imaginação do público. Este personagem pode ser representado de formas diversas, mas seu propósito e, por consequência, a sua sua jornada, são essencialmente análogas - ou mesmo similares. "Seja o herói ridículo ou sublime, grego ou bárbaro, gentio ou judeu, sua jornada sofre poucas variações no plano essencial", explica Campbell (1997, p. 21). Naturalmente, há variações no decorrer do desenvolvimento das formas de disseminação destas narrativas. Enquanto a tradição oral costuma narrar a ação heroica a partir de suas peripécias físicas, por exemplo, as religiões buscam enfatizar a elevação do espírito ou as conquistas morais obtidas através do martírio do salvador. Contudo 
as variações na ordem da aventura, nos papéis de cada um dos personagens da história e sobretudo nos sentidos atribuídos à luta do bem contra o mal são apenas conjunturais, mas não estruturais. Ou seja, se o contexto condiciona as particularidades, a estrutura universaliza as narrativas.

Por isso, as mesmas qualidades dos heróis clássicos de mitologias ancestrais podem ser facilmente reconhecidas na literatura e no cinema contemporâneo, como no famoso bruxo Harry Potter dos livros e do cinema, ou em Luke Skywalker, em Star Wars. No entanto, em outros tipos de narrativas, como comerciais de TV, clipes de música e reportagens jornalísticas, também é possível identificar elementos da Jornada do Herói. É o que vimos em Je Suis Charlie: mesmo se tratando de uma obra considerada não-ficção, é possível identificar elementos simbólicos e mitológicos manipulados para atribuir determinados sentidos à história.

Os chamados "documentários de representação social”, ou filmes de não-ficção, explica Nichols (2005), buscam representar, de forma tangível, os mais diversos aspectos da realidade. A partir dos recursos do cinema, tornam o mundo visível e audível a partir das representações formuladas pela direção do cineasta.

Esses filmes também transmitem verdades, se assim quisermos. Precisamos avaliar suas reivindicações e afirmações, seus pontos de vista e argumentos relativos ao mundo como o conhecemos, e decidir se merecem que acreditemos neles. Os documentários de representação social proporcionam novas visões de um mundo comum, para que as exploremos $\mathrm{e}$ compreendamos (NICHOLS, 2005, p. 27).

Contudo, apesar das diferenças com o cinema de ficção, não é incomum observar documentários utilizando práticas e convenções tradicionais da ficção, tal como "roteirização, encenação, reconstituição, ensaio e interpretação" (NICHOLS, 2005, p. 17). Para sugerir uma correspondência fiel entre imagem e realidade, reforçando a impressão de veracidade a cenas que, na prática, foram deliberadamente construídas, documentários chegam a empregar tecnologias avançadas para aplicar efeitos a partir de lentes, desfoque, distorções, contrastes, profundidade de campo, iluminação, cor e até mesmo granulação ou pixelização artificial para reduzir a qualidade das imagens e sugerir autenticidade. Daí o interesse da presente pesquisa, cujo enfoque é a análise das estruturas mitológicas desta narrativa documental.

A pesquisa no campo da mitocrítica se interessa pela análise das formas simbólicas presentes nas mais diversas obras de arte e produtos midiáticos. Em termos metodológicos, os 
passos contemplam a observação da redundância dos temas míticos nas imagens e narrativas; a conexão do cenário, dos personagens e das situações com esses mitos; e a observação das lições que o mito oferece para atribuir sentido e, assim, solucionar as perplexidades da realidade social presente. Para isso, segundo Durand (2013), é preciso, antes de tudo, identificar e analisar os mitemas - ou seja, fragmentos de mitos, patentes ou latentes, que se revelam através de estereótipos, analogias e metáforas obsessivas percebidas precisamente na redundância de determinados temas no decorrer da obra. Nas palavras de Durand (1985), a mitocrítica realiza uma espécie de "caça" ao mito, que jamais deixou de se participar, de forma implícita ou explícita, das narrativas que os seres humanos criam e interagem.

\title{
3 A JORNADA DO HERÓI DE CHARLIE HEBDO
}

Já no início da narrativa do documentário, os elementos da jornada do herói começam a aparecer. Para Vogler (2006, p. 93), a abertura de um filme é um momento bastante importante, pois deve arrebatar o espectador, sugerindo a ele quais serão a carga e o ritmo da narrativa. A imagem de abertura, que nunca é aleatória, é um recurso particularmente precioso para induzir a imaginação do espectador a determinada direção. Para isso, diretor deve escolher uma metáfora visual para evocar os conflitos e dualidades que movimentarão o segundo ato, recuperando elementos da memória coletiva e instigando a imaginação para os desafios míticos que aguardam os protagonistas.

A cena inicial do documentário Je Suis Charlie (Figura 1) exibe as ruas de Paris e de outras cidades tomadas multidões de manifestantes unidos em favor do jornal. Vários cartazes com o slogan "Je suis Charlie", com mensagens de apoio e reproduções dos desenhos dos cartunistas, também são explorados nas imagens. A narração contextualiza a catarse sugerida pela cena:

\begin{abstract}
Após os massacres de 7, 8 e 9 de janeiro, é uma alegria estar entre nobres parisienses fervorosos. Quatro milhões de nós saímos às ruas da França, dois milhões só em Paris, números não vistos desde a Liberação de Paris. Mas o que nos trouxe a isto, a reconhecer que os cartunistas são guardiões dos nossos grandes valores republicanos? É como se a França, que havia supostamente parado de acreditar em qualquer coisa, tivesse acordado de um longo sono. Estávamos lá para honrar as 17 vítimas dos ataques recentes. (JE SUIS CHARLIE, 2015)
\end{abstract}

Desde o início, portanto, o espectador é introduzido na atmosfera heroica criada em torno de Charlie Hebdo, incluindo o martírio, o senso de coletividade dos "nobres franceses fervorosos", a ressureição da crença da união em nome da libertação do país, e a honra diante 
os "guardiões" dos "grandes valores republicanos". As manifestações de união coletiva são um dos rituais políticos mais importantes para enfrentar o mal que, nas crenças tradicionais, “vem de uma certa divisão que não sabemos explicar" (GIRARDET, 1987, p. 142). Por isso, o retorno do bem depende de uma força contrária: para confrontar o diabólico (aquilo que separa), recorre-se ao simbólico (aquilo que une).

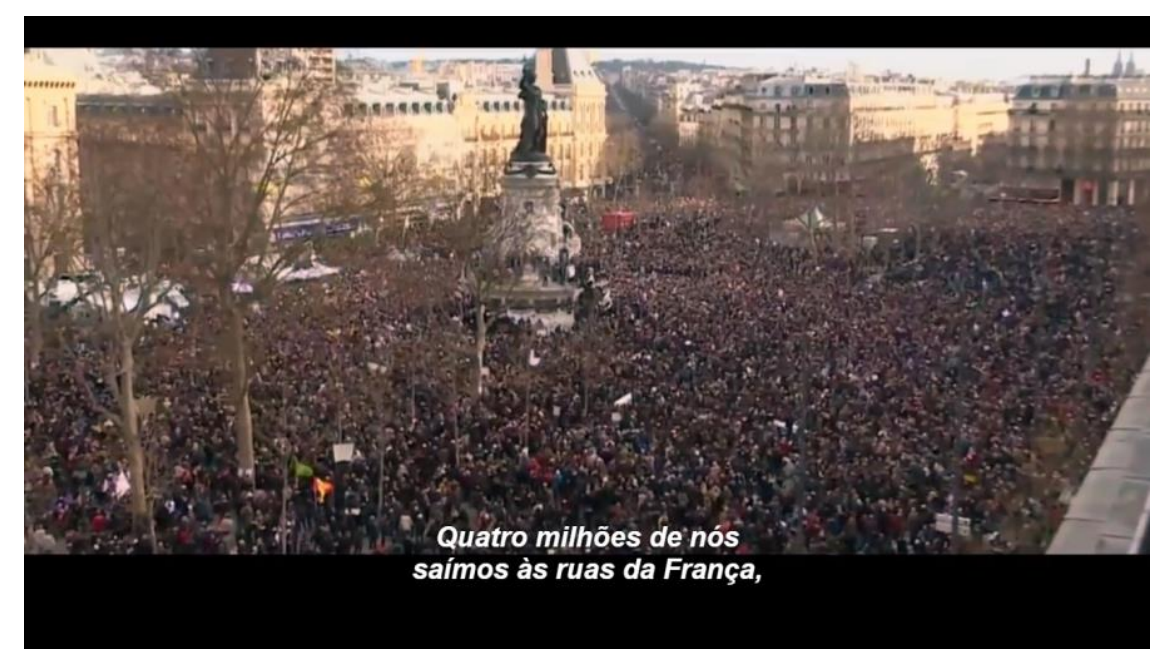

Figura 1. Milhares de franceses vão às ruas em apoio a Charlie Hebdo Fonte: Captura de tela / Je Suis Charlie

Em seguida, o documentário volta a 2007, quando Charlie Hebdo foi processado por organizações do Islã na França. Nestas cenas os cartunistas são exibidos concedendo entrevistas e falando sobre o seu dia-a-dia no jornal. Na estrutura da jornada do herói, eles estão em seu "Mundo Comum", nas tarefas rotineiras de sua atividade criativa. Apesar das tensões por conta do processo judicial, os cartunistas se mostram confiantes, felizes, com ar de vencedores. Essas cenas introdutórias inspiram a familiaridade e o reconhecimento da bravura cotidiana dos cartunistas de Charlie Hebdo, indicando o tom que a narrativa irá seguir.

Ao longo da sequência inicial, várias cenas se intercalam na construção da imagem de um jornal legendário que passa por inúmeros desafios e provações, mas que se mantém intacto, graças ao espírito de luta dos cartunistas. A apresentação do personagem ordinário é muito importante: nas mais diversas narrativas orais, o herói surge como um homem comum, mas que cresce e se transforma a partir de sua jornada. Das sombras do desespero, brota a esperança. Da fraqueza do herói mais improvável nasce a força que vence o poderoso inimigo. A ingenuidade se transcende em sabedoria. "Essas jornadas emocionais é que 
agarram uma plateia e fazem com que valha a pena acompanhar uma história. (VOGLER, 2006, p. 35)

Outra característica importante na construção do herói, tal como observado por Vogler (2006), são os momentos em que o espectador consegue identificar seus desejos e fantasias projetados sobre os personagens do filme. A função dramática do aspirante a herói é justamente levar a plateia vislumbrar, pelo buraco da fechadura, a grande aventura que o aguarda. Por isso, cada espectador que ouve a história é levado a um processo de identificação com o herói, para que possa testemunhar o mundo a partir de suas experiências e sensibilidades. Por isso as mitologias constroem heróis através de uma combinação de características que aliam propriedades universais e únicas. "Os heróis têm qualidades com as quais todos nós podemos nos identificar e nas quais podemos nos reconhecer (VOGLER, 2006, p. 53).

Os diretores de Je Suis Charlie exploraram esses recursos narrativos de maneira deliberada ao apresentar as diversas facetas do herói - os funcionários que lá trabalhavam e Charlie Hebdo em si - para humanizar o jornal, fazendo com que o espectador se familiarize com aquelas pessoas e se identifique com as suas emoções, tornando-se fraternos e solidários diante a tragédia.

\subsection{A sombra}

Outra forma simbólica que podemos identificar com precisão no documentário é a Sombra - ou seja, o vilão da trama, o inimigo da humanidade e adversário do herói, a figura diabólica que pretende destruir não apenas o protagonista, mas o mundo como um todo. Para que a imagem do herói possa ser devidamente consolidada, ele precisa necessariamente de um antagonista que vai impor os desafios que devem ser enfrentados e superados.

O arquétipo da sombra, explica Jung (2002), personifica os traços inferiores de caráter e outras tendências que o sujeito não reconhece em si, mas que, por isso mesmo, sempre o importunam. Precisamente por não reconhecer o mal que o habita, a sombra costuma ser projetada nos outros. Nesse sentido, a criação de um inimigo, explicam Zweig e Abrams (2004), cumpre um propósito vital: atribuir aos outros as sombras que não enxergamos em nós mesmos. Por isso, nos roteiros que empregam as estruturas míticas, os conflitos entre heróis e vilões sintetizam essa dialética. E o arquétipo da Sombra, ao 
representar a energia do lado obscuro da personalidade humana, se expressa em monstros e vilões ávidos por destruir o herói.

A função da Sombra no drama é desafiar o herói e apresentar a ele um oponente à altura em sua luta. As Sombras criam conflito e trazem à tona o que o herói tem de melhor, ao colocá-lo numa situação que ameaça sua vida. Costuma-se dizer que uma história é tão boa quanto seu vilão, porque um inimigo forte obriga o herói a crescer no desafio. (VOGLER, 2006, p. 84)

Em Je Suis Charlie, a Sombra é representada, evidentemente, pelos terroristas responsáveis pelo ataque. Eles não só planejaram derrotar os heróis - os cartunistas da revista - como de fato conseguem matá-los.

Como vimos, durante a história de Charlie Hebdo, a relação entre os islâmicos e o jornal foi sempre conflituosa. Encarando esses acontecimentos por uma perspectiva unilateral, grupos muçulmanos já eram considerados a "Sombra" de Charlie por muito tempo, sempre apresentando desafios para a liberdade de expressão dos cartunistas franceses. Essa representação do povo árabe - ou do povo muçulmano - como sendo a Sombra, o lado obscuro, o inimigo a ser enfrentado, o "outro" em oposição a "nós", é um problema amplamente analisado por Said (2007). No caso de Charlie Hebdo, ambos os assassinos eram árabes, filhos de pais argelinos, vivendo na França: essa característica foi bastante explorada em todas as mídias para reiterar a imagem da Sombra.

Nos documentários e nos noticiários, o árabe é sempre mostrado em grandes números. Nada de individualidade, nem de características ou experiências pessoais. A maioria das imagens representa fúria e desgraça de massas, ou gestos irracionais (por isso, irremediavelmente excêntricos). Espreitando por trás de todas essas imagens está a ameaça da jihad. Consequência: o medo de que os muçulmanos (ou árabes) tomem conta do mundo. (SAID, 2007, p. 383)

Não cabe a este trabalho refletir sobre as implicações dessa forma de representação sobre o mundo árabe e os impactos que acarretam. Analisando o documentário por uma perspectiva mitológica, no entanto, fica claro quem são as Sombras que devem ser reprimidas. E ao observar o teor das publicações do jornal por muitos anos, com charges que satirizavam Maomé (JORNAL, 2015) e os seguidores da religião, percebe-se que Charlie Hebdo já encarava o povo islâmico como Sombra muito antes do atentado ser consumado. O 
documentário tampouco reconhece as sombras que integram a sociedade francesa: a projeção do mal é eminentemente maniqueísta.

\subsection{Provação e Ressurreição}

Um dos elementos identificados por Vogler como indispensáveis à jornada do herói é a "Provação", o clímax da narrativa, no último limiar da vida, quando que o herói precisa morrer para renascer em seguida. É nesse momento que há uma identificação total do público com o personagem: o espectador se sente ofegante com a dimensão dos desafios que o protagonista enfrenta. O martírio é uma das principais fontes da magia do mito. Se no desenrolar do roteiro o objetivo era estimular a identificação dos espectadores com o herói e a sua trajetória, nos momentos finais o espectador é levado a projetar na narrativa todas as emoções e dilemas da iminência de morte. "O resultado desse reviver é uma sensação de entusiasmo e euforia" (VOGLER, 2006, 43).

No documentário, a estrutura é expressa sobretudo a partir da cena em que a cartunista Coco, uma das sobreviventes, conta em detalhes o que havia acontecido minutos antes do atentado.

$\mathrm{Na}$ hora, eu não fazia ideia do que estava acontecendo. Achei que fosse uma piada, foi tão repentino. Estava em estado de choque. Eu não sabia o que estava acontecendo. Foi tudo tão rápido que foi impossível reagir. No estado de pânico que estava, parei no primeiro andar por engano. Eles diziam: "sem piadas, sem piadas.". Foi aí que eu pensei que fosse morrer. Coloquei as mãos atrás da cabeça. Entrei em pânico. Foi quando me dei conta, depois de ir para o andar de cima, que tudo poderia acabar bem ali. Naquele momento, entre o primeiro e o segundo andar, onde fica a edição, eles me disseram que eram Al-Qaeda Iêmen. Quando ouvi Al-Qaeda Iêmen fiquei completamente paralisada. Segurando as armas junto do corpo, eles me mandavam ir mais rápido... Então, subi as escadas. $\mathrm{Na}$ porta, eles me mandaram inserir o código. Eles diziam "Nós queremos o Charb!” (...) Conforme inseria o código, eu podia sentir o Kalashnikov nas minhas costas. Estava pensando na minha filha... Estava completamente arrasada." (JE SUIS CHARLIE, 2015)

A Ressurreição é um segundo momento de grande importância na Jornada do Herói.

De acordo com Vogler, frequentemente este momento reproduz, com intensidade renovada, os desafios de morte e renascimento da Provação. "A morte e a escuridão fazem um último esforço desesperado, antes de serem finalmente derrotadas.” Este clímax é o teste final do herói, que deve demonstrar a todos e a si mesmo, de forma definitiva, que aprendeu, enfim, as lições da Provação. "O herói se transforma, graças a esses momentos de morte e 
renascimento, e assim pode voltar à vida comum como um novo ser, com um novo entendimento (VOGLER, 2006, p. 45).

A história de Charlie Hebdo pode ser interpretada como repleta de momentos de provações e ressureições. O discurso da ressurreição final, no entanto, seria formulado a partir da morte dos cartunistas. Nesse momento, o Herói - o próprio jornal Charlie Hebdo - parecia completamente destroçado. Na narrativa do documentário, o público foi levado a crer que o jornal não se reergueria novamente. No entanto, a publicação de uma nova edição na semana seguinte após o atentado (Figura 2) foi a prova de que a revista continuava viva e mais forte do que nunca.

Os Heróis nos ensinam a lidar com a morte. Eles podem sobreviver, provando que a morte não é tão dura. Podem morrer (ainda que simbolicamente) e renascer, provando que ela pode ser transcendida. Podem morrer uma morte de Herói, quando transcendem a morte, ao oferecer suas vidas por uma causa, um ideal, um grupo (VOGLER, 2006, p. 55).

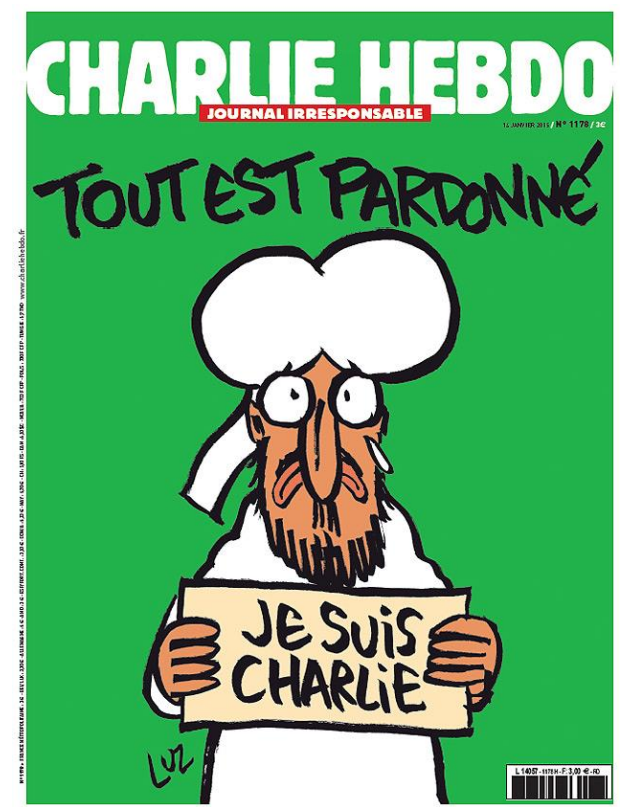

Figura 2. Capa da edição do Charlie Hebdo pós-atentado.

Fonte: Charlie Hebdo

Eric Portheault, gerente adjunto de Charlie Hebdo, fala no documentário sobre a decisão de publicar a nova edição:

Nós falávamos para nós mesmos que não podíamos deixá-los vencer. Publicaríamos uma nova edição da melhor forma que pudéssemos. (...) Queríamos mostrar que eles não morreram em vão. Conforme saíam do prédio, eles gritavam "Matamos Charlie Hebdo!". Nós queríamos mostrar 
que não mataram. Eles haviam destruído o Charlie, mas não o mataram. (JE SUIS CHARLIE, 2015).

A cartunista Coco também relembra desse momento heroico para a publicação. Observamos que ela se refere à força que utilizaram nesse momento como "sobre-humana" qualidade que, mais uma vez, reitera a ideia de um Charlie Hebdo heroico, com capacidades que vão além daquelas de um ser humano comum.

Foi difícil, foi exaustivo, mas sentíamos a necessidade de fazer isso. Houve lágrimas... Pensando bem, não sei que tipo de força sobre-humana nos ajudou a publicar aquela edição. (...) Não sei como, mas conseguimos. Estávamos felizes, felizes por termos feito isso, felizes por eles, por nós... Por muitos motivos. (JE SUIS CHARLIE, 2015)

Por fim, depois das batalhas enfrentadas, há o momento da Recompensa (ou de “apanhar a espada”) do Herói. É o momento em que o Herói finalmente pode respirar aliviado, com o sentimento de dever cumprido. Ora, depois de sobreviver às provações, derrotar o dragão, aprisionar o monstro ou liquidar o vilão, o herói - e por projeção, toda a plateia - têm motivos para celebrar. "O herói, então, pode se apossar do tesouro que veio buscar, sua Recompensa. Pode ser uma arma especial, como uma espada mágica, ou um símbolo, como o Santo Graal, ou um elixir que irá curar a terra ferida (VOGLER, 2006, p. 43).

A recompensa de Charlie Hebdo foi o reconhecimento internacional e o apoio em massa do público francês, além dos oito milhões de exemplares vendidos após o atentado, dos milhões de euros recebidos em apoio e do slogan "Je suis Charlie", cultuado e reverberado pelo mundo todo.

Logo cedo de manhã, milhões de franceses fizeram fila para comprar uma das três milhões de cópias impressas durante a noite. Mais de oito milhões de cópias impressas para atender à demanda. Uma loucura. Como se eles quisessem reinvindicar uma pequena porção dessa tragédia para dizerem que é sua. (JE SUIS CHARLIE, 2015)

Diferentemente da ficção, em que a tensão no espectador causada pela morte iminente do herói é sanada quando se descobre que o herói conseguiu sobreviver, na realidade apresentada pelo documentário isso não acontece, porque os cartunistas estão de fato mortos. No entanto, a "vida após a morte" de Charlie Hebdo se dá quando a edição após o ataque é publicada, como uma forma de mostrar que o atentado, apesar de ter matado pessoas, não foi capaz de calar a publicação. Charlie Hebdo, depois de arruinado, renasce ainda mais forte. A 
repercussão do atentado e os resultados que vieram a partir disso foram apresentados como recompensas antes inimagináveis na história da revista.

Em poucos meses, conta Cohen (2015), aquela publicação alternativa, que apesar de sua história editorial mantinha um futuro incerto, ameaçado pelo desinteresse dos leitores e pelo consequente encolhimento dos lucros, foi transformado em uma verdadeira galinha dos ovos de ouro. Pessoas que jamais haviam sequer ouvido falar do jornal passavam a reproduzir o slogan onipresente "Je suis Charlie". A edição imediatamente posterior ao atentado vendeu em torno de oito milhões de cópias, um número inimaginável para um veículo daquele porte. As assinaturas do jornal, que não passavam de 10 mil, rapidamente alcançaram 200 mil exemplares. Com esses resultados, somados às milhares de doações, o irreverente Charlie Hebdo, jornal que zombava de todas as formas de poder, havia se viabilizado como um periódico influente e financeiramente robusto.

\section{CONSIDERAÇÕES}

A análise de Je Suis Charlie nos mostrou que o documentário fez uso deliberado de formas simbólicas e narrativas mitológicas para conferir significado a uma tragédia que causou comoção mundial. O próprio título do documentário induz ao maniqueísmo de "nós, os franceses"; e "eles, os muçulmanos". Elementos da jornada do herói se constituíram como peças estruturais da narrativa: a própria marca Charlie Hebdo foi representada com uma aura de heroísmo: uma entidade que teve de enfrentar vários desafios ao longo de sua trajetória, culminando no atentado de 2015. Os dois assassinos responsáveis pelo ataque representaram, por sua vez, a Sombra da narrativa, a figura obscura que justifica o clamor pelo Herói e que deve ser derrotada. Mas apesar de a violência ter de fato causado a morte de diversas pessoas e ter deixado Charlie Hebdo abalado, o desfecho não foi capaz de destruir a publicação, que ressurgiu na semana seguinte, de modo triunfal. Ao contrário de muitos roteiros ficcionais, em que a morte é atenuada em uma metáfora, no documentário os heróis morrem literalmente, mas sobrevivem metaforicamente, "vencendo" os inimigos através da consagração de sua obra.

Concluímos, portanto, que a estrutura narrativa do documentário, desde a cena de abertura até os últimos momentos, percorre etapas decisivas da jornada do herói mitológico, de modo que a obra, ao lado de seu evidente valor documental, contribuiu no processo de mitificação do Charlie Hebdo no imaginário ocidental. 


\section{REFERÊNCIAS}

CAMPBELL, Joseph. O Herói de Mil Faces. São Paulo: Cultrix, 1997.

COHEN, Roger. Charlie Hebdo's multi-million-dollar pile of tragedy money. Vanity Fair. Estados Unidos, ago. 2015. Disponível em: https://www.vanityfair.com/news/2015/07/charlie-hebdo-moneyin-france. Acesso em: 2 jan. 2020.

DURAND, Gilbert. Sobre a exploração do imaginário, seu vocabulário, métodos e aplicações transdisciplinares: mito, mitanálise e mitocrítica. Revista da Faculdade de Educação, São Paulo, v. 11, n. 1-2, p. 244-256, dec. 1985. ISSN 1806-9274. Disponível em: http://www.journals.usp.br/rfe/article/view/33348. Acesso em: 2 jan. 2020.

. As Estruturas Antropológicas do Imaginário: introdução à arquetipologia geral. São Paulo: WMF Martins Fontes, 2013.

GIRARDET, Raoul. Mitos e mitologias políticas. São Paulo: Cia das Letras, 1987.

HIGGINS, Andrew; BAUME, Maia de La. Two Brothers Suspected in Killings Were Known to French Intelligence Services. The New York Times. New York, 8 Jan. 2015. Disponível em: https://www.nytimes.com/2015/01/08/world/two-brothers-suspected-in-killings-were-known-tofrench-intelligence-services.html?_r=1. Acesso em: 2 jan. 2020.

JORNAL Charlie Hebdo já havia sido atacado por charge de Maomé. G1. São Paulo, 7 jan. 2015. Disponível em: http://g1.globo.com/mundo/noticia/2015/01/revista-charlie-hebdo-ja-havia-sidoatacada-por-charge-de-maome.html. Acesso em: 2 jan. 2020.

JUNG, C. Os arquétipos e o inconsciente coletivo. Petrópolis: Editora Vozes, 2002.

MOSCARIELLO, A. Como Ver um Filme. Lisboa: Editorial Presença LDA, 1985.

NICHOLS, Boll. Introdução ao documentário. Campinas: Papirus, 2005.

SAID, Edward W. Orientalismo: o Oriente como invenção do Ocidente. São Paulo: Companhia das Letras, 2007.

VEJA cronologia com polêmicas da 'Charlie Hebdo' e ataques à publicação. Folha de S. Paulo. São Paulo, 7 jan. 2015. Disponível em: http://www1.folha.uol.com.br/mundo/2015/01/1571630-vejacronologia-com-polemicas-da-charlie-hebdo-e-ataques-a-publicacao.shtml. Acesso em: 2 jan. 2020.

VOGLER, Christopher. A jornada do escritor: estruturas míticas para escritores. 2 ed. Rio de Janeiro: Nova Fronteira, 2006.

VONOYE, F.; GOLIOT-LÉTÉ. Ensaio sobre a análise fílmica. 4 ed. Campinas, São Paulo: Papirus, 1994.

ZWEIG, Connie; ABRAMS, Jeremiah. (Org.) Ao encontro da sombra: o potencial oculto do lado escuro da natureza humana. São Paulo: Cultrix, 2004. 


\section{Referências audiovisuais}

JE Suis Charlie. Direção de Daniel Leconte e Emmanuel Leconte. Produção de Daniel Leconte. França: Film en Stock, 2015. Disponível em:

https://www.netflix.com/title/80079253. Acesso em: 2 jan. 2020.

Mestre em Comunicação pela Universidade Estadual de Londrina (UEL)

\section{André Azevedo da Fonseca}

Professor Associado na Universidade Estadual de Londrina (UEL).

Doutor em História (Unesp) com pós-doutorado no PACC (UFRJ).

\section{(9) (1)}

Esta obra está licenciada com uma Licença

Creative Commons Atribuição-NãoComercial-CompartilhaIgual 4.0 Internacional 